\title{
Geosciences at the service of society: the path traced by Antonio Stoppani
}

\author{
STEFANIA LUCCHESI \\ PhD geologist, Fiano Romano (RM) - Italy \\ srstefanialucchesi@libero.it
}

\begin{abstract}
Sometime ago, the Italian geologist Antonio Stoppani (1824-1891) highlighted the importance of Earth sciences for education, cultural awareness, development and progress of society. In his introduction of the concept "Anthropozoic Era", he stressed the importance of human beings as a real "geological agent", but also emphasized that mankind has the capacity and the responsibility to contribute to an ethical management of georesources. Currently many consider him one of the "fathers of geoethics", since he introduced some of the geoethical criteria that should guide researchers, scholars, professionals and decision makers in the field of Earth Sciences. Among these ideas, he enhanced the dimensions of beauty and harmony of nature as foundations of Geo-conservation and Geodiversity and the necessity for interdisciplinary collaboration between physical and human sciences, including ethics, to manage the complexity of the ecosystem, for the assessment and mitigation of risk, and for a more integrated growth of human beings while in synergy with the environment.
\end{abstract}

\section{WHO WAS ANTONIO STOPPANI?}

S toppani was born in Lecco (Lombardy, Northern Italy) in 1824 in a modest patriarchal family. The historical context in which he lived is characterized by strong political and social struggles in relation to the establishment of the unification of Italy, events that deeply affected also his scientific career.

After studying philosophy and theology, in 1848 he became a priest and began teaching Latin, literature and music. He openly expressed his liberal ideas and participated actively in the independence wars of Italy in 1848-49 against the Austro-Hungarian Empire, but unfortunately, given his ideas and active political participation, he was discharged from his teaching position and considered as dangerous by the Austrian Chancellery.

Despite these events, his reputation as a scholar allowed him to find employment as a teacher for a family in Milan, where he could also devote himself more assiduously to geology and paleontology.

In 1856 he published his first great scientific work Studi geologici e paleontologici sulla Lombardia (Geological and paleontological studies of Lom- bardy), a true "revelation to scientists and to himself" (Nangheroni, 1975) that earned him the nickname as the "founder of Italian geology" by his contemporaries.

In 1860, he obtained the high school teaching qualification in Natural History from the Government for his talents and abilities in the field of the natural sciences, even though he had never received a degree.

In 1861, he was named "Outstanding Teacher" of geology at the University of Pavia, in 1863 he taught geognosy (a field comprehensive of lithology, stratigraphy and paleontology) and applied mineralogy at the Regio Istituto Tecnico of Milan, the future Politecnico, and from 1865 to 1868 he became curator of the Civic Museum of Natural History in Milan.

In 1874 he was appointed president of the Italian Society of Natural Sciences, then in 1875 he was elected honorary member of the Pontifical Academy of Nuovi Lincei and in 1877 the Ministry of Education awarded him the title of Officer of the Order of the Crown of Italy for "the 
high services he presents in public education" (Redondi, 2009).

From 1877 to 1882 he was the chair of geology at the Istituto di Studi Superiori Pratici e di Perfezionamento in Florence, in 1882 he became director of the Museum of Natural Sciences and Philosophy in Milan and lastly he taught geology at the Istituto Tecnico Superiore until his death in 1891.

The results of his studies are contained in many scientific works, but also in more informal writings, both entertaining and didactic works. Among the major examples: Studi geologici $e$ paleontologici sulla Lombardia (Geological and paelontological studies on Lombardy) (1856), Paleontologie Lombarde (Paleontology of Lombardy) (1856-1881), Rivista geologica della Lombardia in rapporto con la carta geologica della regione (Geological review of Lombardy in relation with the geological map of the region) (1859), Corso di geologia (Course of geology) (1871-1873), a treaty in three volumes on geology, petrography and geomorphology, L'ambra nella storia e nella geologia (The amber in history and geology) (1886), but also some more popular works such as Il Bel Paese (The beautifull contry) (1875) and Acqua ed aria, la purezza del mare e dell'atmosfera (Water and air, the purity of the sea and of the atmosphere) (1875).

\section{STOPPANI'S CONTRIBUTION TO GEO- EDUCATION AND GEOETHICS}

Stoppani was an eclectic man with many interests and passions that blended with a great commitment to the different areas that affected his life: science, literature, education, social and political commitment, and faith.

$\mathrm{He}$ is regarded by his contemporaries and scholars of all time as "a great scientist, a great naturalist, a great geologist" (Nangheroni, 1975). His passion for the Earth sciences began as a child as a spontaneous inclination and from 1850 onwards he devoted himself with more assiduity to the study of geology, paleontology, geomorphology and metamorphic petrography of Northern Italy, but also of the Middle East and Northern Africa.

In 1865 he was appointed chairman of the Special Section on Prehistory at the International Congress of Prehistoric Anthropology in La Spezia (Italy). Later, he started to build the $\mathrm{Mu}$ - seum of Natural Sciences in Milan with the purpose to make available to the general public the knowledge gained by science, and in particular the "treasures of nature", such as those kept in museum collections. The museum opened in 1892, one year after his death.

Stoppani is perhaps best known to the public as a great lecturer, conversationalist and disseminator for Earth sciences. He was considered "the poet of geology" by his contemporaries, thanks to his outgoing character and the enthusiasm used in his lessons and expositions. His passion communicated what he believed, that "every mountain, every rock, every stone, every grain of earth, has a record to tell us" (Stoppani, 1971-1973). Even Pope Pius XI (1857-1939) said that "he had the incredibly beautiful gift of an enviable disclosure [...] so great was in him the art to exhibit and to make easy and understandable the scientific thought. Dressing with beauty any scientific truth was his constant concern" (Leucensis, 1921).

His artistic temperament and his popular science vein were highlighted with Il mare glaciale $a^{\prime}$ piedi delle Alpi (The glacial sea at the base of the Alps) (1874) and he reached his most fame with Il Bel Paese (1875) that made him one of the first Italian writers who started the art of educating the scientific knowledge through storytelling. Il Bel Paese, commonly used as schoolbook, consists of thirty "conversations" where an uncle, the Author himself, in a colloquial form, but

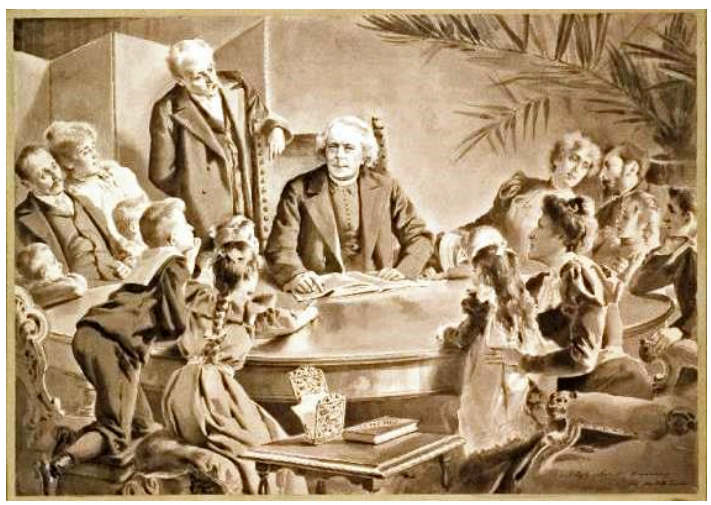

Figure 1: Stoppani teaching sciences of Italy (Il Bel Paese) to his grandchildren and friends (drawing by E. Magistretti preserved at the Natural History Museum of Lecco, Italy). 
with scientific rigor, describes the natural beauty, geology and physical geography of Italy to an audience represented by grandchildren and their friends (Fig. 1). This work had a dual purpose: first, it made accessible to Italian citizens the knowledge of the beauties of their country, convinced that "we should start with the 'know yourself', by knowing that the physical and natural history of their own country" (Stoppani, 1875); next, his work aimed to include the literary genre of science fiction, like that of Jules Verne (1828-1905), as well as to affirm the search of truth from a scientific point of view.

\section{THE BASES OF GEOETHICS AND THE IMPORTANCE OF EARTH SCIENCES IN CULTURAL AND SOCIAL GROWTH}

Stoppani is one of the first scientists who understood and communicated the significance of Earth sciences as a means for cultural and hu- man growth of society. This may be appreciated as a precursor to geoethical thinking.

In particular, he realized that human beings, with the use of reason, are able to change nature and to actively shape the Earth surface, and thus define humans as a real "geological agent." Having understood the importance of human impact on nature, he felt the need to introduce in the Corso di geologia (Course of geology" (1871-1873) the concept "Anthropozoic Era" for defining the latest geological period in which human action began to be significant and decisive in the evolution dynamic of the Earth. This intuition, that somehow anticipates the modern concept of Anthropocene (Crutzen, 2002; Steffen et al., 2004), can be considered a preamble of the thought which would deepen later, in nineteenth century, with the birth of geoethics (Peppoloni and Di Capua, 2012; Bobrowsky et al., 2017).

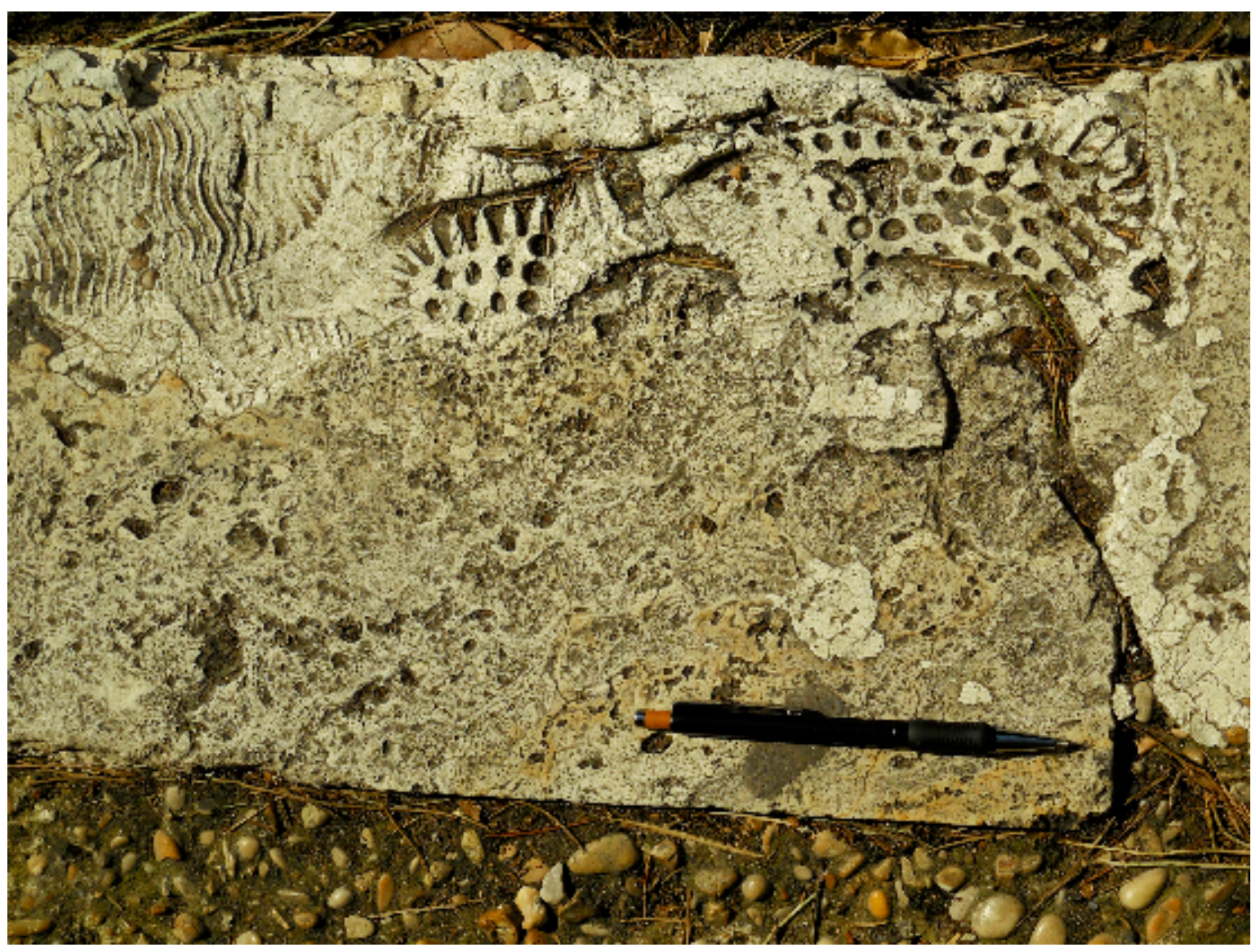

Figure 2: Urban fossil on a sidewalk of the city of Rome (Italy): the travertine sedimentary structures are juxtaposed to the human footprints in cement. 
The intuition of an "Anthropozoic Era", as well as other concepts developed by Stoppani, highlights the topicality and foresight of his conception of science. Below are some of the main pillars on which he developed his thinking and scientific approach, and that can be considered as the basis of geoethical thinking.

\subsection{HUMAN BEINGS AS A GEOLOGICAL AGENT}

Stoppani, in the chronological description of the events that have characterized the different geological times, following the Neozoic Age, describes the "Anthropozoic Era" and divides it into Stone Age, Bronze Age and Iron Age. In this context, human beings are defined as "an agent, perhaps new, certainly still inexperienced of his power, ... called upon to put the last touches to the work of the ages" (Stoppani, 1871-1873). In his vision it is therefore clear that "Man" is the last of the agents involved in the evolution of the Earth, a "new agent" able to "impose itself on nature" (Stoppani, 1871-1873), to interact with it and to modify it with its action (Fig. 2).

From the awareness that human beings have of their action and ability to alter the dynamics of nature comes the responsibility that one has in respect to the Earth system (Bobrowsky et al., 2017): through knowledge and progress, human beings can actively promote geoconservation and sustainable development respectful of nature and society (Peppoloni and Di Capua, 2016).

These issues have been included in the "Geoethical Promise" (Matteucci et al., 2014), intended as an oath for geoscientists in relation to their responsibilities towards the Earth, society and future generations (Di Capua et al., 2016).

\subsection{SCIENCE AS A SERVICE TO THE TRUTH THROUGH THE ANALYTICAL- EXPERIMENTAL METHOD}

In the Exemeron (1894), Stoppani examines the validity of the experimental method of analysis in scientific research, which consists mainly of a collection of research and experiential data, using reasoned comparison of phenomena and researching their causes according to an inductive process (Stoppani, 1873 and 1894). He believes that only by using this approach could geology take on the role of a science and give a systematic approach to scientific research. At the same time Stoppani asserts that intellectual speculation must also deal with its own limits as the history of science demonstrates: scientific research is performed through a continuous process of partial achievements and mistakes that allow it to reach, a bit at a time, some truth (Stoppani, 1894).

This method, although now accepted as part of scientific research, is relevant not only for its methodological meaning, but also for its values. This method commits us to look for and then communicate the objectivity seen and known by experimentation. Only later, after a phase of data collection, can a series of elaborations, interpretative models and evolutionary scenarios be drawn, but remembering that they are still in the context of interpretations and one cannot claim to be absolutely certain. As a consequence, the objectivity and limits of the results of scientific research are to be declared also in the dissemination phase for the principle of intellectual honesty (Peppoloni et al., 2015).

Stoppani claims that "sciences are called to give a service to the truth" (Stoppani, 1894) thus highlighting the value that Earth sciences have in overcoming ignorance, searching the common good for society, promoting geoconservation and developing a geoethical approach in environmental management and introducing geoethics in scientific curricula (Peppoloni and Di Capua, 2016; Vasconcelos, 2016; Bobrowsky et al., 2017; Stewart and Gill, 2017).

\subsection{THE EARTH AS A GLOBAL HERITAGE TO BE PRESERVED IN ITS UNIQUENESS AND GEODIVERSITY}

The great value attributed by Stoppani to the natural sciences is linked to his conception of planet Earth, perceived as a reality that has in itself its own sacredness. Therefore for its preciousness and uniqueness is an asset to be preserved (Stoppani, 1875 and 1881). 


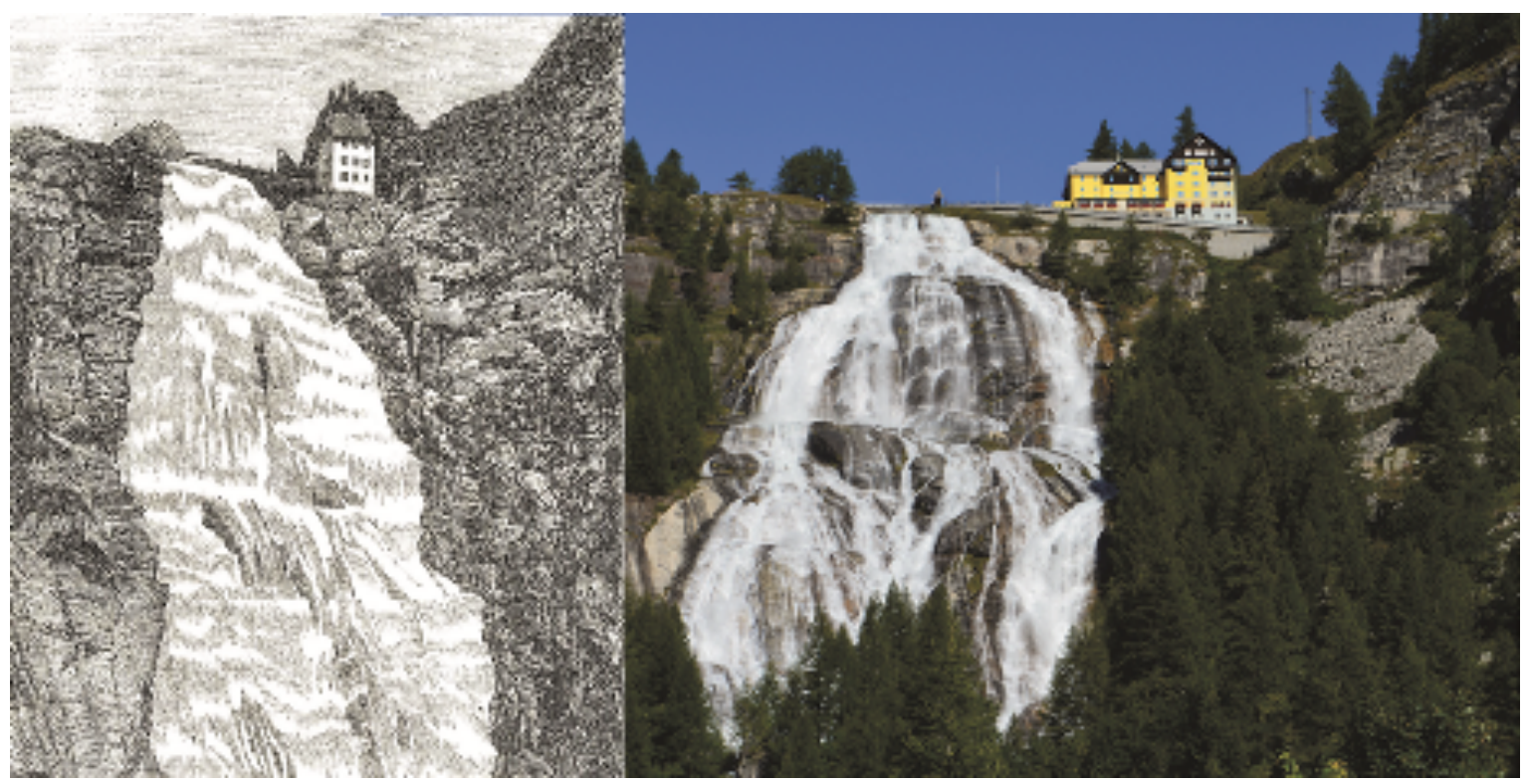

Figure 3: The Toce fall (Verbania, Italy) in a drawing of 1875 from Il Bel Paese (Stoppani, 1875) (left) and in a recent photo (right).

He underlines how often the "image of nature" unconsciously reminds all of a sort of "sacred" value that can be found in nature. The recognition of this value is linked to the dimensions of beauty and harmony of nature that are at the basis of geoconservation and the protection of geodiversity (Lucchesi and Giardino, 2012).

In this context, Stoppani promoted the educational role of the scientific museum for a positive "globalization" and popularization of knowledge (Greco, 2007). He was also one of the first admirers of "geosites", of those places that for their scientific, environment and cultural value are to be considered true monuments of nature and part of the geological and geomorphological heritage of an area (Reynard, 2003) (Fig. 3).

\subsection{HOLISTIC VIEW OF SCIENCE AND MANKIND}

For Stoppani science was always at the service of mankind, and therefore also scientific progress, as it is part of human progress, should be respectful of every person (Stoppani, 18711873). However, he believed as a critical point in the separation between scientific knowledge and human sciences and highlighted the need for a unified vision of knowledge in order to avoid a segmentation due to a partial or sectoral approach to the truth. He argued that the fragmentation of knowledge is a cause of error and cannot lead to a global response in a complex world ((Stoppani, 1873).

Today more than ever, we are facing a strong fragmentation of knowledge that often does not allow one to have an integrated vision of human beings. That is why Stoppani affirmed the need to grow within an interdisciplinary dialogue, marked by unity and distinction between scientific research and human sciences, between physical and metaphysical sciences, between science and ethics.

A unified vision of science is therefore critical to the search for the integral good of human beings in the various dimensions that characterize their life and society, for the growth of the common good, the development of peoples and a responsible citizenship. Such an integrated approach to science, including its economic, ethical, social, and cultural impact, is presently fundamental to manage the complexity of the 
Earth system (Mejlgaard and Bloch, 2012; Bobrowsky et al., 2017).

\subsection{THE EARTH SYSTEM}

One of the most innovative and also modern aspects of Stoppani's thoughts is the vision of the Earth that he conceived as a "great machine [...] governed by a Supreme Principle" that exists through a continuous and simultaneous competition including antagonism from endogenous agents, physical forces, chemical and mechanical properties, that "are called to entertain what you can call globe life", but which also contribute to "the biological forces [...] order to maintain that wonderful circle in motion, that noble balance, so there is variety together with units "(Stop- modern approach to the study of the Earth system from a perspective of dynamic relationships between the various components of the ecosystem. This vision is now indispensable for environmental protection, proper management of georesources, evaluation and risk mitigation, all closely related with geoethical issues and common good (Fig. 4).

\section{CONCLUSIONS}

Stoppani as a passionate scholar of Earth sciences was able to use his knowledge and his professional skills for training, education and human promotion of the society of his time.

The contribution of Stoppani is therefore of great significance in establishing the criteria that should guide, also nowadays, researchers,

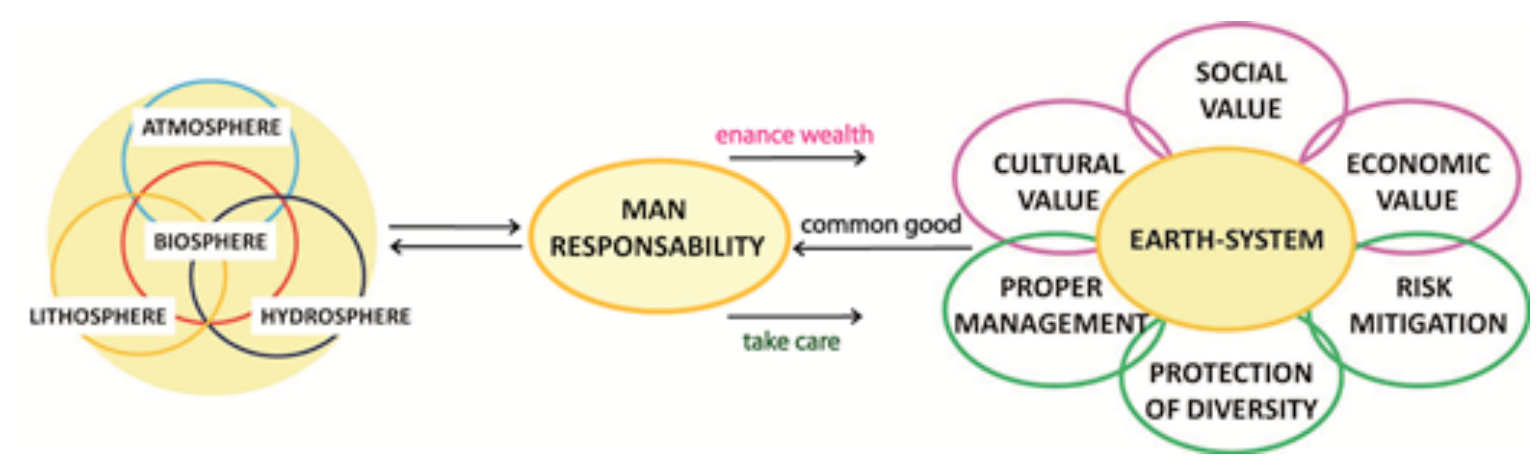

Figure 4: Sketch of the dynamic relations inside the Earth system and their interconnection and relationship with human's responsibility.

pani, 1871-1973 and 1873). For Stoppani the force that maintains the balance in the world, considering the complexity and the relational system that characterizes the Earth, is the continuous antagonism of natural agents.

In this sense, Stoppani approaches the more recent Gaia hypothesis by James Lovelock and Lynn Margulis, that conceives the Earth as a single organism in which living and non-living things are connected to each other by negative retroactive processes that tend to maintain the stability of the main parameters that allow life on the planet (Lovelock, 1979).

Stoppani, albeit in the simplicity of his language and based on the knowledge of his time, seems to have launched the foundations for a scholars, educators, professionals and decision makers in their work and activities in the field of Earth sciences according to a geoethical approach. His importance is also due to his commitment to Earth sciences education as mean to improve a proactive citizenship among the Italian people, a great challenge that today has become a worldwide necessity.

Rightfully he should be considered as one of the fathers of geoethics and geoeducation.

\section{REFERENCES}

Bobrowsky P., Cronin V.S., Di Capua G., Kieffer S.W. and Peppoloni S. (2017). The Emerging Field of Geoethics. In: Scientific Integrity and Ethics with Applications to the Geosciences, edited by Gundersen L.C. 
Special Publication American Geophysical Union, John Wiley and Sons, Inc.

Crutzen P.J. (2002). Geology of mankind. Nature, 415: 23.

Di Capua G., Peppoloni S. and Bobrowsky P. (2016). The Cape Town Statement on Geoethics. With the contributions of Bilham N., Bohle M., Clay A., Lopera E.H., Mogk D. IAPG - International Association for Promoting Geoethics.

Greco P. (2007). Science museums in a knowledge-based society, Journal of Science Communication, 6(2): 1-3.

Leucensis (1921). Antonio Stoppani, Stab. Tipografico L'Italia, Soc. Anonima ed., Milano.

Lovelock J. (1979). Gaia, A New Look at Life on Earth, Oxford University.

Lucchesi S. and M. Giardino (2012). The role of geoscientists in human progress, Annals of Geophysics, 55(3): 355-359.

Matteucci R., Gosso G., Peppoloni S., Piacente S. and Wasowski J. (2014). The Geoethical Promise: A Proposal, Episodes, 37(3): 190191.

Mejlgaard N. and Bloch C. (2012). Science in Society in Europe, Science and Public Policy, 39(6): 695-700.

Nangheroni G. (1975). Antonio Stoppani (18241891): natura, patria, religione, Atti Soc. It. Sc. Nat. Museo Civ. St. Nat., Milano, 116(34): 161-182.

Peppoloni S., Bobrowsky P. and Di Capua G. (2015). Geoethics: a challenge for the research integrity in geosciences. Integrity in the Global Research Arena, pp. 287-294, In: Steneck N., Anderson M., Kleinert S., and Mayer T., Eds. Integrity in the Global Research Arena, World Scientific Publishing Co.

Peppoloni S. and Di Capua G. (2012). Geoethics and geological culture: awareness, responsibility and challenges. In: Peppoloni, S. and Di Capua, G. (eds.). Geoethics and geological culture. Reflections from the Geoitalia Conference 2011, Annals of Geophysics, Special Issue, 55(3): 335-341.

Peppoloni S. and Di Capua G. (2016). Geoethics: Ethical, social, and cultural values in geosciences research, practice, and education. pp. 17-21. In: Wessel, G.R., and Greenberg, J.K., Eds. Geoscience for the Public Good and Global Development: Toward a Sustainable Future: Geological Society of America Special Paper 520, 2016.
Redondi P. (2009). Stoppani in cattedra, Nuovi documenti sull'insegnamento della geologia nel secondo Ottocento, Istituzioni, attori e ideali di un secolo di cultura scientifica a Milano 1863 - 1963, Lettera del Ministero della Pubblica Istruzione a Francesco Brioschi al direttore del R. Istituto Tecnico Superiore di Milano, Roma, 27 luglio 1877. www.milanocittadellescienze.it

Reynard E. (2003). "Geosites" definition. In: Routledge Encyclopedia of Geomorphology, ed. Goudie A., School of Geography and the Environment, University of Oxford.

Steffen W., Sanderson A., Tyson P.D., Jäger J., Matson P.A., Moore B. III, Oldfield F., Richardson K., Schellnhuber H.J., Turner B.L. and Wasson R.J. (2004). The Anthropocene Era: how humans are changing the Earth system. In: Global Change and the Earth System: a Planet under pressure, SpringerVerlag Berlin Heidelberg New York, 81-141.

Stewart I.S. and Gill J.C. (2017). Social geology integrating sustainability concepts into Earth sciences. Proc. Geol. Assoc., 128 (2): 165-172.

Stoppani A. (1871-1873). Corso di geologia, 3 voll., Bernardoni, Milano.

Stoppani A. (1873). Acqua ed aria ossia la purezza del mare e dell'atmosfera fin dai primordi del mondo animato. Conferenze. Società Editrice Internazionale, Tip. Salesiana, Torino.

Stoppani A. (1875). Il Bel Paese, Conversazioni sulle bellezze naturali la geologia e la geografia fisica d'Italia, Agnelli, Milano.

Stoppani A. (1881). Lo studio della natura come elemento educativo, In: I trovanti. Il sentimento della natura e la Divina Commedia, Discorsi accademici, Necrologie. Agnelli ed., Milano.

Stoppani A. (1894). Exemeron, storia della creazione, Unione Tipografico Editrice, Torino.

Vasconcelos C., Torres J., Vasconcelos L. and Moutinho S. (2016). Sustainable development and its connection to teaching Geoethics. Episodes, International Journal of Geosciences, 39(3): 509-517. 